\title{
Bloodstream Infections Caused By Carbapenem- resistant Enterobacteriaceae: Risk Factors, Treatment and Effects on Mortality
}

\section{Karbapenem Dirençli Enterobacteriaceae'nın Etken Oldug̃u Kan Dolașımı İnfeksiyonları: Risk Faktörleri, Tedavisi ve Mortalite Üzerine Etkileri}

\author{
Dilek BULUT'1(IID), Gönül ÇiçEK ȘENTÜRK²(İD)
}

\footnotetext{
${ }^{1}$ Clinic of Infectious Disease and Clinical Microbiology, Van Regional Training and Research Hospital, Van, Turkey

${ }^{2}$ Clinic of Infectious Disease and Clinical Microbiology, Dıșkapı Yıldırım Beyazıt Training and Research Hospital, Ankara, Turkey
}

\begin{abstract}
Introduction: Antimicrobial resistance is a global crisis that threatens the success of modern medical approaches. This is due to the emergence, spread, and persistence of multidrug-resistant bacteria, especially carbapenem-resistant Enterobacteriaceae (CRE).

Materials and Methods: In this study, bloodstream infections caused by Enterobacteriaceae in our hospital were investigated retrospectively. As design, a retrospective cohort case-control study was used. Patients with CRE induced bloodstream infections (CREBSI) were identified as the case group while patients with carbapenem-susceptible Enterobacteriaceae induced bloodstream infections (CSEBSI) were identified as the control group. Demographic characteristics, risk factors, clinical and mortality data and treatment results were
\end{abstract} compared in both groups.

Results: Mean age of the case and control groups was $68.9 \pm 17.0$ years and $59.3 \pm 18.0$ years, respectively. Age $(p=0.006)$, Charlson Comorbidity Index (CCI) ( $p=0.002)$, and hospitalization in the intensive care unit (ICU) $(p=0.001)$ were found as risk factors for CREBSI. Previous use of antibiotics was identified as independent risk factors for CREBSI. Mortality indicators for all patients with bloodstream infection were identified to be diabetes mellitus (DM) ( $p=0.041), A P A C H E-I I$ score $(p<0.001), C C I(p=0.005)$, and use of any antibiotic before culture $(p<0.001)$ in the univariate analysis. The only and independent mortality indicator was detected to be APACHE-Il score in all patients with both CREBSI and CSEBSI $\left(p<0.001,0 R_{\text {adj }}: 1.3 ; 95 \% \mathrm{CI}, 1.2-1.5\right)$. The presence of CREBSI was not identified as a risk factor for mortality in the multivariate analysis $(p=0.074)$. Survival time was longer in the case group patients who received combination therapy compared to the monotherapy patients.

Conclusion: CREBSI threatens elderly patients, patients with comorbidity, patients hospitalized in the ICU for a long period of time and former use of antibiotics. Since all patients with both CREBSI and CSEBSI have a single and independent mortality indicator APACHE-II score, unnecessary antibiotic use can be avoided. In addition, strict infection control measures should be taken to control these infections.

Key Words: Bloodstream infection; Carbapenem-resistant Enterobacteriaceae; Carbapenem-susceptible Enterobacteriaceae; Mortality, Treatment 


\title{
ÖZ \\ Karbapenem Dirençli Enterobacteriaceae'nın Etken Oldug̃u Kan Dolașımı İnfeksiyonları: Risk Faktörleri, Tedavisi ve Mortalite Üzerine Etkileri
}

\author{
Dilek BULUT', Gönül ÇiçEK ȘENTÜRK²
}

\author{
1 Van Eg̃itim ve Araștırma Hastanesi, İnfeksiyon Hastalıkıarı ve Klinik Mikrobiyoloji Klinig̃i, Van, Türkiye \\ ${ }^{2}$ Dıșkapı Yıldırım Beyazıt Eg̃itim ve Araștırma Hastanesi, İnfeksiyon Hastalıkları ve Klinik Mikrobiyoloji Klinig̃i, Ankara, Türkiye
}

Giriş: Antimikrobiyal direnç, modern tıbbi yaklaşımların başarısını tehdit eden küresel bir sorundur. Bunun en önemli nedenlerinden biri de çok ilaca dirençli bakterilerin, özellikle karbapenemlere dirençli Enterobacteriaceae (KDE)'lerin ortaya çıkması ve yayılmasıdır.

Materyal ve Metod: Bu çalışmada, hastanemizde Enterobacteriaceae'nin neden olduğu kan dolaşımı infeksiyonları geriye dönük olarak incelenmiştir. Tasarım olarak retrospektif kohort vaka-kontrol çalışması kullanılmışır. Karbapenem dirençli Enterobacteriaceae ilişkili kan dolaşımı infeksiyonu (KDEiKDi) olan hastalar olgu grubu, karbapenem duyarlı Enterobacteriaceae ilişkili kan dolaşımı infeksiyonları (KDuEiKDi) olan hastalar kontrol grubu olarak tanımlandı. Her iki grupta demografik özellikler, risk faktörleri, klinik ve mortalite verileri ve tedavi sonuçları karşılaştırılmıştır.

Bulgular: Olgu ve kontrol gruplarının yaş ortalaması sırasıyla $68.9 \pm 17.0$ yıl ve $59.3 \pm 18.0$ yıl olarak saptanmıştır. Çalışmamızda, yaş $(p=0.006)$, serebro-vasküler olay (SVO) $(p=0.007)$, alzaymır hastalığı varlığı $(p=0.005)$, charlson komorbidite indeksi (CKi)'nin yüksek olması $(p=0.002)$ ve yoğun bakım ünitesinde yatış $(Y B U ̈)(p=0.001)$ KDEiKDi için risk faktörü olarak bulunmuştur. Daha önce antibiyotik kullanımı da KDEiKDi için bağımsız risk faktörü olarak saptanmıştır. Çalışmaya dahil ettiğimiz kan dolaşımı infeksiyonu olan tüm hastalarda, diyabetes mellitus (DM) $(p=0.041)$, alzaymır $(p=0.020)$, APACHE-II skoru $(p<0.001), C K i$ 'nin yüksek oluşu $(p=0.005), Y B U ̈$ 'de yatış $(p<0.001)$ ve kültür öncesi herhangi bir antibiyotik kullanımı $(p<0.001)$ tek değişkenli analizde mortalite için risk faktörleri olarak tanımlanmıştır. Hem KDEiKDi hem de KDUEiKDi'li tüm hastalarda tek ve bağımsız mortalite göstergesi APACHE-II skoru olarak tespit edilmiştir $\left(p<0.001, O R_{a d j}: 1.3 ; \% 95 \mathrm{Cl}, 1.2-1.5\right)$. KDEiKDi varlığı, çok değişkenli analizde mortalite için bir risk faktörü olarak tanımlanmamıştır ( $p=0.074)$. Kaplan-Meier'in sağkalım eğrisine göre, hayatta kalma süresi, antibiyogramdan sonra kombinasyon tedavisi alan hastalarda monoterapi alan hastalara göre daha uzun bulunmuştur.

Sonuç: KDEIKDi'ler yaşlı, komorbiditesi olan, YBÜ'de uzun süre yatan ve daha önce antibiyotik kullanan hastaları tehdit etmektedir. Hem KDEiKDi hem de KDuEiKDi olan tüm hastalarda tek ve bağımsı mortalite göstergesi APACHE-Il skoru olduğundan, gereksiz antibiyotik kullanımından kaçınılabilir. Ayrıca, bu infeksiyonları kontrol altına almak için sıkı infeksiyon kontrol önlemleri alınmalıdır.

Anahtar Kelimeler: Kan dolaşımı infeksiyonları; Karbapenem dirençli Enterobacteriaceae; Karbapenem duyarlı Enterobacteriaceae, Mortalite; Tedavi

\section{INTRODUCTION}

Bloodstream infections caused by carbapenem-resistant Enterobacteriaceae (CRE) have become an important problem in many parts of the world and are associated with high mortality (40-60\%). A favorable effect in terms of reduced mortality has been observed in patients treated with the colistin-based combination therapy. With the increase of colistin use, resistance of Enterobacteriaceae to colistin and thus, mortality due to the infections caused by these microorganisms will also increase $e^{[1]}$.

Regarding a multicenter study conducted in 2008 in Turkey, imipenem, meropenem and doripenem resistances against the Enterobacteriaceae isolates were $2.1 \%, 1.7 \%$ and $2.1 \%$ respe- ctively $^{[2]}$. On the other hand, according to Central Asian and Eastern European Surveillance of Antimicrobial Resistance (CAESAR) annual report on 2018 data, the rate of carbapenem-resistant Klebsiella species was $25-50 \%$ in the blood and cerebrospinal fluid samples in Turkey, and the same rate was greater than $50 \%$ in Greece ${ }^{[3]}$. As is seen, resistance rate has increased very fast over the years. If necessary measures are not taken and the principles of antibiotic use are not appropriately determined, resistance in the CRE species will make a domino effect as mentioned in the paragraph above and cause the development of resistance to the next antibiotics. Hence, infections related to CRE are an important and increasing public health problem due to limited treatment options ${ }^{[4]}$. 
In this study, our objective was to determine the demographic characteristics of the patients, in whose blood culture CRE was isolated, the risk factors related to this infection, the efficacy of the administered treatment and the relationship between the infection and mortality.

\section{MATERIALS and METHODS}

\section{Study design}

In this study, bloodstream infections caused by Enterobacteriaceae in our hospital were investigated retrospectively. As design, a retrospective cohort case-control study was used. Patients with carbapenem-resistant Enterobacteriaceae induced bloodstream infections (CREBSI) was identified as the case group while patients with carbapenem-susceptible Enterobacteriaceae induced Bloodstream infections (CSEBSI) was identified as the control group. Inclusion criteria for the selection of patients were: hospitalization in the service or intensive care unit on the specified dates; inclusion of blood circulation infection in the definition of hospital infection or health care-related infection. Patients under the age of 18 were not included into the study. Forty people who met these criteria were identified as the case group patients and 80 people as the control group patients. The first growth in blood culture in both groups was included in the analysis. Recurrent infections were excluded. CRE colonization was not taken into account in either the case or the control groups.

Clinical features, demographic data, laboratory data and vital follow-up of the patients were retrieved from patient files, hospital information management system and patient follow-up forms of the Infection Control Committee, and nurse observations were recorded in patient files, as well.

In our study, isolates were selected according to the presence of resistance against one of the mentioned carbapenems (imipenem, meropenem and ertapenem) or the presence of the documented carbapenemase production in compliance with the "Guidance for Control of Carbapenem-Resistant Enterobacteriaceae", which was modified and published by the Center for Disease Cont- rol (CDC) in 2015[6]. The blood cultures were incubated with the BACTEC automated blood culture system. VITEK 2 microbial identification (ID) automated system (BioMérieux), API $20 \mathrm{E}$ (BioMérieux) semi-automated system and conventional methods were used for the identification of Enterobacteriaceae species isolated in the blood cultures. Antibiotic susceptibility testing (AST) was investigated according to the Clinical and Laboratory Standards Institute (CLSI) criteria between 2012 and 2014 and according to the European Committee on Antimicrobial Susceptibility Testing (EUCAST) criteria between 2015 and 2016 with VITEK 2 AST (BioMérieux) and gradient diffusion test (E Test BioMérieux) method for colistin.

The Source of Bloodstream infections (BSI): The same bacterial strain that grows in the blood culture is also grown in the culture of foci such as urine, tracheal aspirate and wound. If the bacteria was only grown in the blood culture, it was taken as primary Bloodstream infection.

The Appropriate Antibiotic Definition: The presence of in vitro sensitivity of the identified microorganism to the initiated empirical treatment. Only strains susceptible to AST were included in this definition and strains with mild susceptibility were not included.

Time before treatment: The time interval between the blood culture and the start of the suitable treatment according to the result of the antibiotic susceptibility test. Unnecessary expansion of the treatment according to the antibiotic susceptibility test result was excluded.

\section{Statistical Analysis}

Descriptive and advanced analyses were done with SPSS Statistics V23.0, Open Epi and Excel software programs. Regarding data analysis, 95\% CI (confidence intervals), 5\% error margin, numeric and percentage distributions, odds ratio (OR) were used for the calculations.

A logistics model was created in order to evaluate the risk factors associated with carbapenem-resistance in multi-variant analyses. Charlson Comorbidity Index (CCI), Intensive Care Unit (ICU) Admission, antibiotics used prior to growth in blood (carbapenem, piperacillin/tazobactam, $3^{\text {rd }}$ 
generation cephalosporin) were included in the model. When deciding on the variables to be included in the model, variables with $p<0.05$ and those considered to be clinically important were included in the univariate analysis, and then, these variables were determined by the stepwise method. In addition, variables were examined in terms of effect change, and no effect change was found.

The second model was developed for all patients, and risk factors affecting mortality were evaluated in all patients. "CCI, Acute Physiology and Chronic Health Evaluation II (APACHE II) Score, Carbapenem resistance and positive inotropic need" were included in this model. When deciding on the variables to be included in the model, variables with $\mathrm{p}<0.05$ and those considered to be clinically important were included in the univariate analysis and then, these variables were selected by the stepwise method. Variables were also examined in terms of effect change, and no effect change was found.

In addition, risk factors affecting mortality in patients with carbapenem resistance were also attempted to be examined by multivariate analyzes, but this evaluation could not be made since the number of patients to be included in the model was limited.

Chi-square and Fisher's exact Chi-square tests were used for the comparison of the categorical variables, and Independent Student's t-test was used for the evaluation of the difference between the mean values. 95\% CI, OR $\mathrm{Odj}_{\text {lj }}$ (odds ratios adjusted) and Wald test were used for logistic regression analysis.

Kaplan-Meier analysis was used for the evaluation of the effect of the treatment administered after the antibiotic susceptibility test in patients with carbapenem resistance on survival rates. In this analysis, Log Rank test and Tarone-Ware test results were used for the evaluation of the effect of the monotherapy and combination therapy in patients with carbapenem resistance on the survival rates, and the difference between the therapies and the survival rates of the patients were shown in a table. The survival curve was drawn for 30-day mortality.

\section{RESULTS}

\section{Demographic and epidemiological cha- racteristics}

Between 01.08.2012-30.06.2016, 40 patients with CREBSI were included in the case group and 80 patients with CSEBSI included in the control group. Female patients accounted for $60 \%$ of all patients. Their mean age was $68.9 \pm 17.0$ years. $53.8 \%$ of the patients in the control group were females, and their mean age was $59.3 \pm 18.0$ years $(p=0.006)$. The most common diagnosis during hospitalization was pneumonia in the case group ( $n=10 ; 25 \%$ ). The most common hospitalization in the case group was in the ICU of the internal medicine department (30\%). The most common hospitalization in the control group was in the clinics of the internal medicine (37.5\%). In the case group, the most frequent factor was found to be $K$. pneumonia. On the other hand, $E$. coli was determined to be the most frequent factor in the control group. Bacteria that grew in the blood culture in the case and control groups are shown graphically in Figure 1.

\section{Risk Factors For the Development of CREBSI (Univariate and Multivariate Analysis)}

Regarding the univariate analysis, risk factors for CREBSI were the age $(p=0.006)$, hypertension as a concomitant disease $(p<0.001)$, cerebrovascular event (CVE) $(p=0.007)$, presence of Alzheimer's disease $(p=0.005)$, CCI $(p=0.002)$, hospitalization in ICU $(p=0.001)$, prolonged hospitalization in ICU $(p=0.016)$, prolonged total duration of the hospitalization $(p=0.036)$, urinary catheterization $(p<0.001)$, presence of an central venous catheter $(C V C)(p=0.039)$, Enterobacteriaceae growth in media except blood in 6 months before the growth in blood $(p=0.012)$, antibiotic use in 6 months before the growth in blood ( $p<$ 0.001 ), use of carbapenem ( $p<0.001)$, piperacillin/tazobactam $(p<0.001)$, and $3^{\text {rd }}$ generation cephalosporins $(p=0001)$. Malignancy was significantly higher in the control group $(p=0.023$; OR: $0.3 ; 95 \% \mathrm{CI}: 0.1-0.9)$. Of the 30 patients with malignancy, 19 had hematologic malignancy and 11 had solid tumor. Risk factors for CREBSI in multivariate analysis are shown in Table I. 


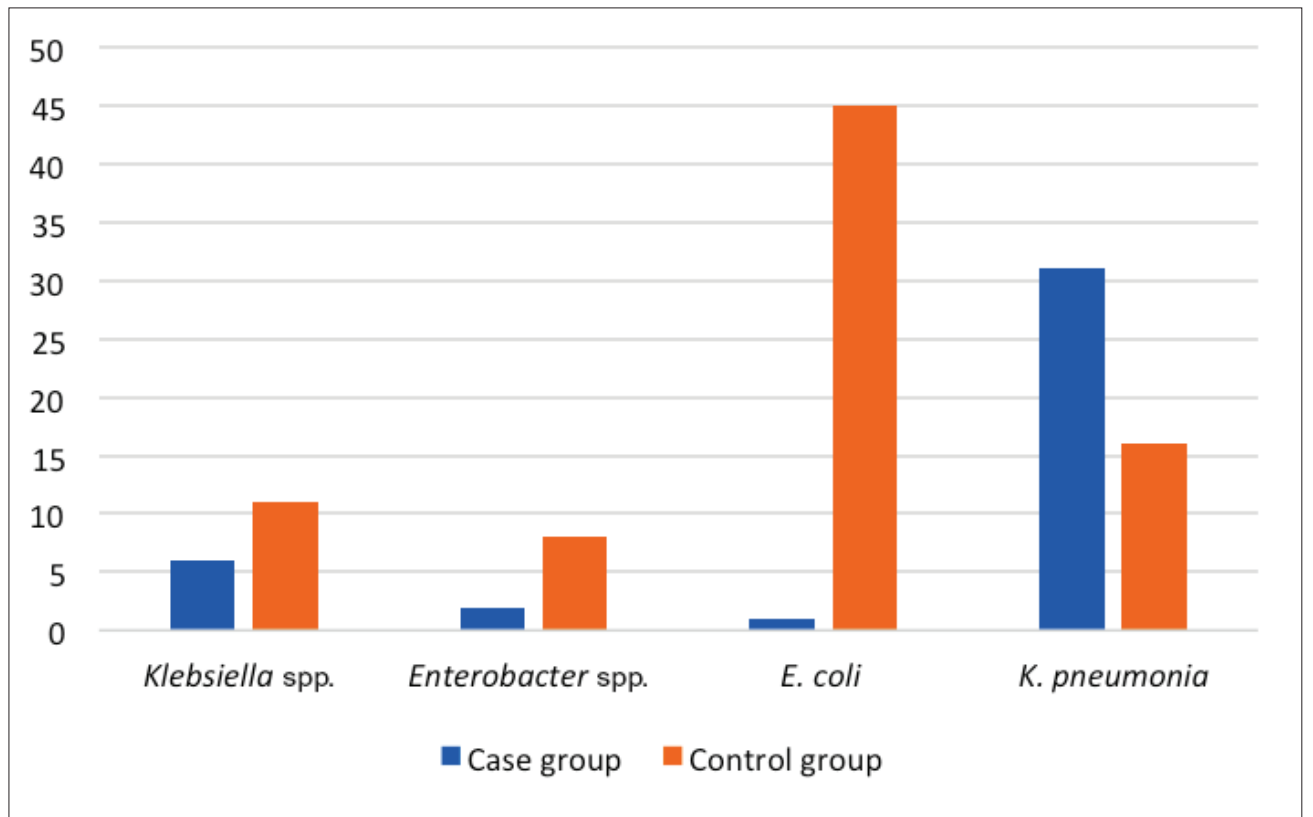

Figure 1. Bacteria that grow in the blood culture of the case and control groups.

Risk factors for mortality (univariate and multivariate analysis)

In the univariate analysis, investigation of the risk factors for mortality in all participating patients showed that the presence of the diagnosis of a concomitant diabetes mellitus (DM) and Alzheimer's disease was more common among the deceased patients $(p=0.041 ; p=0.020$ respectively). The results of the univariate analysis related to mortality are given in Table II.

Median survival time (30 days) was calculated to be 8.4 days in the case group and 18.6 days in the control group. No statistically significant difference was found between the case and the control group in terms of 30-day-survival $(p=0.003)$.

The results of the multivariate analysis of the risk factors related to the mortality in all participating patients are shown in table III.

In the case group, 34 deceased and 6 living patients were compared in respect to the risk factors related to mortality. Among these, APACHE-II score $(p=0.001)$, CKI $(p<0.001)$, inability to respond to fever $(p=0.001)$, diagnosis of primary bloodstream infection $(p=0.039)$, and age were found to be mortality indicators for CREBSI. Factors related to mortality in patients with CREBSI in the univariate analysis are shown in Table IV.

Table 1. Risk factors for CREBSI (Multivariate Analysis)

\begin{tabular}{|c|c|c|c|c|}
\hline Risk factors & CREBSI \% & CSEBSI \% & $\mathrm{OR}_{\mathrm{adj}}(95 \% \mathrm{Cl})$ & $\mathbf{p}$ \\
\hline $\mathrm{CCl}($ Mean $\pm \mathrm{SD})$ & $6.2 \pm 2.4$ & $4.8 \pm 2.1$ & $1.3(1.1-1.6)$ & 0.034 \\
\hline Hospitalization in ICU & 95.0 & 66.3 & $3.2(0.6-16.7)$ & 0.179 \\
\hline \multicolumn{5}{|c|}{ Antibiotic use before the culture } \\
\hline Carbapenem & 50.0 & 18.8 & $4.5(1.6-13.2)$ & 0.005 \\
\hline Piperacillin/tazobactam & 57.5 & 18.8 & $6.3(2.2-17.7)$ & 0.001 \\
\hline $3^{\text {rd }}$ generation cephalosporin & 37.5 & 11.3 & $7.6(2.2-25.8)$ & 0.001 \\
\hline
\end{tabular}


Table 2. Factors related with mortality in all patients (Univariate Analysis)

\begin{tabular}{|c|c|c|c|c|c|c|}
\hline \multirow[t]{2}{*}{ Factors } & \multicolumn{2}{|c|}{$\begin{array}{l}\text { Non-survivors } \\
\quad(n=69)\end{array}$} & \multicolumn{2}{|c|}{$\begin{array}{c}\text { Survivors } \\
(\mathrm{n}=51)\end{array}$} & \multirow[t]{2}{*}{$\mathbf{p}$} & \multirow[t]{2}{*}{ OR $(95 \% \mathrm{Cl})$} \\
\hline & $\mathbf{n}$ & $\%$ & $\mathbf{n}$ & $\%$ & & \\
\hline Age (Mean \pm SD) & \multicolumn{2}{|c|}{$66.6 \pm 16.5$} & \multicolumn{2}{|c|}{$57.0 \pm 19.1$} & 0.004 & - \\
\hline \multicolumn{7}{|l|}{ Comorbid Disease } \\
\hline DM & 27 & 39.1 & 11 & 21.6 & 0.041 & $2.3(1.1-5.3)$ \\
\hline HT & 3 & 50.7 & 17 & 33.3 & 0.057 & $2.1(1.0-4.4)$ \\
\hline CVE & 14 & 20.3 & 4 & 7.8 & 0.059 & $3.0(0.9-9.7)$ \\
\hline Alzheimer's Disease & 7 & 10.1 & - & - & $0.020^{*}$ & - \\
\hline Renal failure & 7 & 10.1 & 2 & 3.9 & 0.298 & $2.8(0.6-13.9)$ \\
\hline Malignancy† & 13 & 18.8 & 17 & 34.0 & 0.060 & $0.5(0.2-1.0)$ \\
\hline APACHE-II & \multicolumn{2}{|c|}{$25.5 \pm 7.1$} & \multicolumn{2}{|c|}{$16.3 \pm 6.1$} & $<0.001$ & - \\
\hline $\mathrm{CCl}$ & \multicolumn{2}{|c|}{$5.8 \pm 2.3$} & \multicolumn{2}{|c|}{$4.6 \pm 2.1$} & 0.005 & - \\
\hline Presence of a CVC & 60 & 87.0 & 35 & 68.6 & 0.015 & $3.1(1.2-7.6)$ \\
\hline Surgery in the last three months & 33 & 47.8 & 22 & 43.1 & 0.679 & $1.2(0.6-2.4)$ \\
\hline Hospitalization in the ICU & 61 & 88.4 & 30 & 58.8 & $<0.001$ & $5.3(2.1-13.5)$ \\
\hline \multicolumn{7}{|l|}{ Antibiotic use before the culture } \\
\hline Carbapenem & 28 & 40.6 & 7 & 13.7 & 0.001 & $4.3(1.7-10.9)$ \\
\hline Piperacillin-tazobactam & 27 & 39.1 & 11 & 21.6 & 0.041 & $2.3(1.1-5.3)$ \\
\hline $3^{\text {rd }}$ generation cephalosporins & 20 & 29.0 & 4 & 7.8 & 0.004 & $4.8(1.5-15.1)$ \\
\hline The duration of the carbapenem use before the culture & \multicolumn{2}{|c|}{$9.9 \pm 16.0$} & \multicolumn{2}{|c|}{$4.0 \pm 10.9$} & 0.018 & - \\
\hline \multicolumn{7}{|l|}{ CREBSI } \\
\hline Yes & 34 & 49.3 & 6 & 11.8 & $<0.001$ & $7.3(2.8-19.3)$ \\
\hline No & 35 & 50.7 & 45 & 88.2 & & \\
\hline Requirement of positive inotropic agent & 28 & 40.6 & 5 & 9.8 & $<0.001$ & $6.3(2.2-17.8)$ \\
\hline Persistent fever & 45 & 78.9 & 2 & 4.7 & $<0.001$ & $76.9(16.1-333.3)$ \\
\hline
\end{tabular}

Table 3. Risk factors for mortality in all patients (Multivariate Analysis)

\begin{tabular}{lcccc} 
Patient characteristics & Non-survivors $\%$ & Survivors $\%$ & OR $_{\text {adj }}(95 \% \mathrm{CI})$ & $\mathbf{p}$ \\
\hline CCI (Mean \pm SD) & $5.8 \pm 2.3$ & $4.6 \pm 2.1$ & $1.2(1.0-1.6)$ & 0.114 \\
APACHE II (Mean \pm SD) & $25.5 \pm 7.1$ & $16.3 \pm 6.1$ & $1.3(1.2-1.5)$ & $<0.001$ \\
CREBSI & 49.3 & 11.8 & $3.4(0.9-12.7)$ & 0.074 \\
Requirement of positive inotropic agent & 40.6 & 9.8 & $3.3(0.7-14.4)$ & 0.121 \\
\hline
\end{tabular}

CREBSI: Carbapenem-resistant Enterobacteriaceae induced bloodstream infections, CSEBSI: Carbapenem-susceptible Enterobacteriaceae induced bloodstream Infections, CCI: Charlson comorbidity index, ICU: Intensive care unit, OR adj: Odds ratios adjusted, Cl: Confidence interval, APACHE II: Acute physiology and chronic health evaluation II, SD: Standard deviation. 
Table 4. Factors related to mortality in patients with CREBSI $(n=40)$ (Univariate Analysis)

\begin{tabular}{|c|c|c|c|c|c|c|}
\hline \multirow[t]{2}{*}{ Factors } & \multicolumn{2}{|c|}{$\begin{array}{l}\text { Non-survivors } \\
\quad(n=34)\end{array}$} & \multicolumn{2}{|c|}{$\begin{array}{l}\text { Survivors } \\
(n=6)\end{array}$} & \multirow[t]{2}{*}{$\mathbf{p}$} & \multirow[t]{2}{*}{ OR $(95 \% \mathrm{CI}) / \mathrm{ES}^{*}$} \\
\hline & $\mathbf{n}$ & $\%$ & $\mathrm{n}$ & $\%$ & & \\
\hline Age (Mean \pm SD) & \multicolumn{2}{|c|}{$74.0 \pm 11.7$} & \multicolumn{2}{|c|}{$40.2 \pm 13.9$} & $<0.001$ & 0.8 \\
\hline APACHE-II & \multicolumn{2}{|c|}{$24.9 \pm 5.9$} & \multicolumn{2}{|c|}{$16.2 \pm 3.0$} & 0.001 & 0.5 \\
\hline $\mathrm{CCl}$ & \multicolumn{2}{|c|}{$6.8 \pm 2.0$} & \multicolumn{2}{|c|}{$2.8 \pm 1.9$} & $<0.001$ & 0.7 \\
\hline Persistent fever & 20 & 76.9 & - & - & $0.001^{\dagger}$ & $12.7(1.3-40.7)$ \\
\hline \multicolumn{7}{|l|}{ Causative agents } \\
\hline Klebsiella spp. & 4 & 11.8 & 2 & 33.3 & $0.215^{\dagger}$ & $0.27(0.04-1.9)$ \\
\hline Enterobacter & 2 & 5.9 & - & - & $1.000^{\dagger}$ & $0.8(0.03-18.8)$ \\
\hline E. coli & 1 & 2.9 & - & - & $1.000^{\dagger}$ & $0.4(0.01-12.1)$ \\
\hline Klebsiella pneumonia & 27 & 79.4 & 4 & 66.7 & $0.602^{\dagger}$ & $1.9(0.3-12.8)$ \\
\hline \multicolumn{7}{|l|}{ Source of BSI } \\
\hline VAP & 9 & 26.5 & 1 & 16.7 & $1.000^{\dagger}$ & $1.8(0.2-17.6)$ \\
\hline Primary bloodstream & 7 & 20.6 & 4 & 66.7 & $0.039^{\dagger}$ & $0.13(0.02-0.9)$ \\
\hline Urinary tract & 9 & 26.5 & - & - & $0.306^{\dagger}$ & $4.3(0.2-85.4)$ \\
\hline Catheter related & 5 & 14.7 & 1 & 16.7 & $1.000^{\dagger}$ & $0.9(0.1-9.0)$ \\
\hline Soft tissue & 3 & 8.8 & - & - & $1.000^{\dagger}$ & $1.2(0.05-26.3)$ \\
\hline Abdominal & 1 & 29 & - & - & $1.000^{\dagger}$ & $0.4(0.01-12.1)$ \\
\hline Colistin resistant bacteria growth in blood culture & 7 & 20.6 & - & - & $0.567^{\dagger}$ & $3.1(0.1-62.6)$ \\
\hline Change of empirical antibiotic treatment & 15 & 44.1 & 6 & 100.0 & $0.021^{\dagger}$ & $0.7(0.5-0.9)$ \\
\hline
\end{tabular}

*Hedges g converted to r, $\dagger$ :Fisher's exact Chi-square test, CREBSI: Carbapenem-resistant Enterobacteriaceae induced bloodstream Infections, CCl: Charlson comorbidity index, APACHE II: Acute physiology and chronic health evaluation II, BSI: Bloodstream infection VAP: Ventilator-associated pneumonia.

\section{Analysis of the Treatment and Clinical Outcome}

CRE isolates were most susceptible to the following three antibiotics: colistin (82.5\%), amikacin (69.2\%) and tigecycline (43.5\%).

The rate of the inappropriateness of the empirically initiated antibiotics was $75 \%$ in the case group and $19.7 \%$ in the control group ( $p<0.001$; OR: 12.2; 95\% CI: 4.9-30.8). Treatment changes in empirical treatments were $52.5 \%$ and $41 \%$ in the case and control groups, respectively $(p=0.236)$.

In the case group, after the antibiogram, 10 (25\%) patients received monotherapy (9 carbapenem, 1 piperacillin tazobactam), 29 (72.5\%) patients a combination consisting of two antibiotics (19 carbapenem + colistin, 3 carbapenem + sulbactam, 7 others combination) and one patient a combination consisting of three antibiotics (1\%).
In 9 of the patients who received monotherapy, escalation could not be done in antibiotic treatment because these patients died when the antibiogram resulted. The last treatment of the living patients in the case group was evaluated, and it was found that 4 of these patients received meropenem and colistin, one patient received imipenem and amikacin and one patient imipenem monotherapy.

The effect of treatment after antibiotic susceptibility test on survival time in patients with CREBSI are shown in Table $\mathrm{V}$.

According to the survival curve of the Kaplan-Meier, after the blood culture, survival time was significantly longer in the combination treatment groups compared to the monotherapy group ( $p=0.026)$. The Kaplan-Meier survival curve analysis in the case group is shown in Figure 2 . 
Table 5. The effect of treatment after antibiotic susceptibility test on survival time in patients with CREBSI

\begin{tabular}{lccccc} 
Survival time & Mean \pm SD & \%95 Cl & Median \pm SD & \%95 Cl & p $^{*}$ \\
\hline Monotherapy & $4.8 \pm 1.4$ & $2.1-7.6$ & $2.0 \pm 3.7$ & $0.0-9.2$ & 0.026 \\
Combination therapy & $70.6 \pm 24.7$ & $22.3-119.0$ & $10.0 \pm 5.4$ & $0.0-20.5$ & \\
Total & $59.8 \pm 20.7$ & $19.1-100.4$ & $8.0 \pm 1.8$ & $4.4-11.6$ & \\
\hline
\end{tabular}

* Log Rank test, Tarone-Ware test, SD: Standard deviation, Cl: Confidence interval, CREBSI: Carbapenem-resistant Enterobacteriaceae induced bloodstream infections

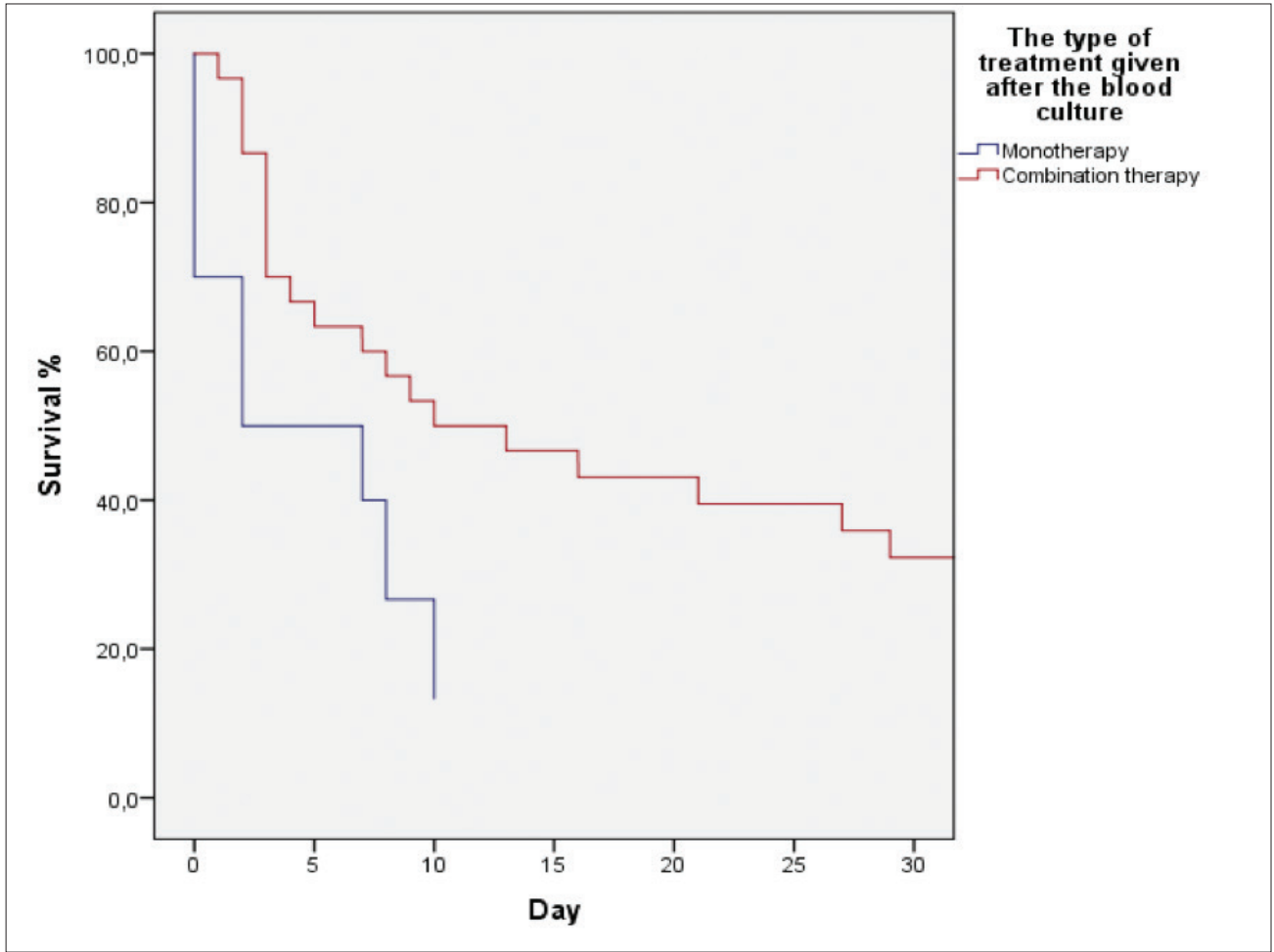

Figure 2. The impact of treatment after antibiotic susceptibility testing on 30-day mortality in patients with CREBSI.

\section{DISCUSSION}

In the past years, several case-control studies focusing on the identification of the risk factors for $\mathrm{CRE}$ have been published ${ }^{[7-9]}$. The studies in the literature focusing on the risk factors have usually reported similar results. The reported main risk factors for CRE acquisition were impaired functional status, severity of the underlying disease, hospitalization in the ICU, and previous exposures to antibiotics ${ }^{[10,11]}$. Our results were also consistent with the literature. Regarding patient-related variables, factors like advanced age, high CCI, CVE and Alzheimer's disease, which impair the functional status of the patients, were identified as risk factors for CRE acquisition in the univariate analysis. In the multivariate analysis, there was a significant difference between the groups regarding the CCI values $(p=0.034$, OR: 1.3; 95\% CI: 1.1-1.6). This finding is consistent with previous studies ${ }^{[12,13]}$

Malignancies are among the risk factors for CRE acquisition in some studies in the literatu$r e^{[14]}$. Interestingly, some studies have also noticed a protective effect of malignant disease for CRE acquisition ${ }^{[12,15]}$. This effect may be related to better hygienic measures and stricter adherence to contact precautions practiced with these patients as well as the high likelihood of the patients 
being assigned to private rooms. In our study, malignancy was found to be a protective factor (OR: 0.3; 95\% CI: 0.1-0.9) for CRE acquisition.

It is well known that antibiotic use is a risk factor for the selection of resistant species. With the increase in the number of antibiotics used and the prolonged treatment of the treatment time, the resistance against antibiotics also increases. Especially in recent years, the term "collateral damage" appears as an important healthcare problem due to unnecessary usage of antibiotics and selection of multidrug antibiotic-resistant pathogens ${ }^{[16]}$. In our study, regarding the results of the univariate analysis, antibiotic use within the last 6 months was a risk factor for the acquisition of CREBSI. In a recent study published in China, previous use of the $3^{\text {rd }}$ and $4^{\text {th }}$ generation cephalosporins $(p<0.001 ;$ OR: 4.57; 95\% CI: 1.971-10.539) and carbapenems ( $p=0.001 ;$ OR: 4.058; 95\% CI: 1.753-9.397) were identified as independent risk factors for CRE infections ${ }^{[17]}$.

In our study, regarding the risk factors for the acquisition of CREBSI, hospitalization in the ICU, prolonged ICU care, long total hospitalization, implementation of a urinary catheter or CVC were statistically significant in the univariate analysis. However, hospitalization in the ICU was not a risk factor in the multivariate analysis. In the study of Correa et al, hospitalization in the ICU, CVC, prolonged CVC, previous antibiotic exposure were related to carbapenem-resistant $K$. pneumonia (CRKp) infection. Prolonged stay of the CVC was an independent risk factor for CRKp acquisition ( $p=0.07$; OR: 1.08; 95\% CI: $1.01-1.16)^{[7]}$. In a similar study, duration of hospitalization, admission to the ICU, CVC, new solid organ and stem cell transplantation, mechanical ventilation, and broad-spectrum antibiotic use were identified as risk factors for CRE acquisition, and these findings were consistent with our study ${ }^{[12,18,19]}$. In the study conducted by Dizbay et al., hospitalization in the ICU was an independent risk factor for CRKp infection in the multivariate analysis $(p=0.022$; OR: 3.36; 95\% CI: $1.193-9.508)^{[20]}$.

Several studies have emphasized that CRE and CRKp infections were related to high rates of clinical failure, high mortality rates, delayed treatment, high rates of the treatment changes, inappropriate empirical treatment, serious clinical condition (septic shock, high APACHE score) ${ }^{[7,18-23]}$.

Studies focusing on the effects of CRE infection on mortality have reported conflicting results. Therefore, the correlation between carbapenem resistance and mortality is still not fully elucidated. According to the study of Schwaber et al., CRKp isolation is the only independent predictor of the intrahospital mortality ${ }^{[12]}$. There are other studies in the literature confirming this data ${ }^{[19,24-26]}$. In another study focusing on the referable mortality of CRKp, crude mortality rate was $71.9 \%$ in the patient group and $21.9 \%$ in the control group, and referable mortality rate was 50\% (95\% CI: 15.3-98.6). This study was not only focused on bacteremia patients as in our study and included also CRKp growth in other parts of the body. Again in this study, the mortality risk rate was 3.3 in the patients with CRKp bacteremia (95\% CI: 2.9-28.5) ${ }^{[11]}$.

In another study focusing on the risk factors of the $K$. pneumonia bacteremia, mortality rate was significantly higher in patients infected with CRKp compared to the patients infected with carbapenem-sensitive species (43\% and 29\% respectively). According to the results of the multivariate analysis, mortality was related to immobility ( $p=0.043$; OR: 2; 95\% CI: 1-3.9), chronic liver disease $(p<0.001 ;$ OR: $5 ; 95 \%$ CI: 1.9-13.3), CCI $\geq 5$ ( $<<0.001$; OR: 6.7; 95\% CI: 2.4-18.8), mechanical ventilation $(p<$ 0.001 ; OR: 4.1; 95\% CI: 2.3-7.3) and dialysis ( $p=0.011$; OR: 2.9; 95\% CI: 1.3-6.5). However, in the multivariate analysis, there was no correlation between the carbapenem resistance and the increased mortality. A proper early-start of the empirical treatment did not prominently affect mortality ${ }^{[14]}$. There are conflicting results regarding the significant relation between carbapenem resistance and mortality $[27,28]$. According to the results of our study, in the univariate analysis, carbapenem resistance was a significant risk factor for mortality. However, according to the results of the multivariate analysis, there was no statistically significant correlation between mortality and carbapenem resistance. 
In the study of Girometti et al., unlike other study models, the APACHE-II score was calculated simultaneously with the positive blood culture, and in $83 \%$ of the study cohort, survival was correctly predicted ( $p<0.0001$; OR: $0.88 ; 95 \%$ $\mathrm{CI}$ : 0.83-0.97). Inadequate empirical treatment, which was another variable included in the multivariate analysis, was twice more strongly correlated with mortality $(p=0.02$; OR: $1.9 ; 95 \% \mathrm{CI}$ : $1.1-3.4)^{[10]}$. Also in our study, in the multivariate analysis, which was done with the combination of both patient groups, the only strong predicting indicator of mortality was the APACHE-II score ( $p<0.001$; OR: 1.3; 95\% CI: 1.2-1.5). In our multivariate analysis, the presence of CREBSI in the patients was not related to mortality. Other factors included in the model $(\mathrm{CCI}$, the requirement of positive inotropy at the start of the treatment) was not significantly related to mortality. Although the number of insufficient empirical antimicrobial treatment was significantly high in the patient group ( $\mathrm{p}<0.001$; OR: $12.2 ; 95 \% \mathrm{CI}$ : 4.9-30.8), on the contrary of the previous study, it was not related to the mortality in the multivariate analysis. Depending on this result, we were not able to explain the negative patient outcomes with the delay of the treatment. This result is consistent with the study of Correa et al. ${ }^{[7]}$.

Although the ideal active treatment is not defined in CRE infections, there are some recommendations which increase survival. Despite the data demonstrating the relationship between the combination therapy and the survival, the optimal combination therapy has not been determined yet ${ }^{[10,22,29,30]}$. Nevertheless, colistin based combined antimicrobial regimes have become the backbone of treatment ${ }^{[23,29-31]}$. Qureshi et al. have reported that the most successful combination in the treatment of CRKp infections was colistin and tigecycline or a carbapenem derivati$v^{[29]}$. Tumbarello et al. have demonstrated that the triple combination consisting of tigecycline, colistin and a carbapenem derivative was independently related to the survival in CRKp infections ${ }^{[22]}$. In our study, regarding the last administered antibiotic treatments to each living patient in the case group, four patients had meropenem and colistin, one patient imipenem and amika- cin and one patient only imipenem. According to the survival curve of Kaplan-Meier, although the survival time was significantly longer in the patients who received combination therapy after the antibiotic susceptibility test compared to the monotherapy patients, we were not able to show a statistically significant empirical or definitive treatment model increasing the survival because of the high mortality and heterogeneous treatments.

The most important limitation of our study is its retrospective design. The prevalence of antibiotic use as a risk factor for blood culture may have exceeded expectations in the study design because the patients in the control group consisted of patients with carbapenem susceptibility. Due to the high mortality in the case group, no further analysis could be done to determine the risk factors of mortality in this group. Again, for the same reason the heterogeneity of the treatment and the inability to assess the effectiveness of therapeutic intervention has been considered as a limitation of our study.

Another limitation of our study is the failure to obtain bacteria strains since the study had a retrospective design. Thus, broth microdilution method could not be employed for colistin susceptibility, as recommended by EUCAST, and gradient diffusion test (E-test) was used.

In conclusion, studies focusing on the relationship between CRE infections and mortality have reported conflicting results. Therefore, the correlation between carbapenem resistance and mortality is still not fully elucidated. These infections threaten particularly the patients, who are old, undergo additional invasive interventions and are exposed to antibiotic use and are hospitalized in the ICU for a long time. Relating the negative outcome in patients with underlying diseases, the absence of appropriate treatment and unnecessarily increasing the dosage and prolonging the duration of the antibiotic treatment increases the number of the resistant bacteria in the endogenous flora and additionally provokes the emergence of additional comorbidities due to the side effects of these treatment in these patients with several comorbidities. Therefore, unnecessary antibiotic use should be avoided, and strict measures for infection control should be implemented. 


\section{ETHICS COMMITTEE APPROVAL}

Approval for this study was obtained from Health Sciences University, Yıldırım Beyazıt Training and Research Hospital Clinical Research Ethical Committee. (Decision no: 36/02, Date: 27.03.2017)

\section{CONFLICT of INTEREST}

No conflict of interest was declared by the authors.

\section{AUTHORSHIP CONTRIBUTIONS}

Concept/Design: GCSS, DB

Analysis/Interpretation: DB, GCS

Data Acquisitation: DB

Writting: DB, GCSS

Final Approval: GCS

\section{REFERENCES}

1. Giacobbe DR, Del Bono V, Trecarichi EM, De Rosa FG, Giannella $M$, Bassetti $M$, et al. Risk factors for bloodstream infections due to colistin-resistant KPC-producing Klebsiella pneumoniae: results from a multicenter case-control-control study. Clin Microbiol Infect 2015;21:1106 e1101-8.

2. Leblebicioglu H, Cakir N, Celen M, Kurt H, Baris H, Laeuffer J, et al. Comparative activity of carbapenem testing (the COMPACT study) in Turkey. BMC Infect Dis 2012;12:42.

3. World Health Organization (WHO). Central Asian and Eastern European surveillance of antimicrobial resistance: annual report 2017; 2018. Erişim tarihi: 1 Ocak 2019. Available from: https://www.euro.who.int/_data/assets/pdf_file/0005/354434/WHO_CAESAR_AnnualReport_2017.pdf

4. Özyazici G, Özkaya E, Kaya H, Sel S, Altinbaşak H, Başari F, et al. Investigation of blaKPC gene by $P C R$ in carbapenem resistant Escherichia coli and Klebsiella pneumoniae clinical isolates in a tertiary care hospital in Turkey. Mediterr J Infect Microb Antimicrob 2019;8:3.

5. Karakullukçu A, Borsa BA, Kuşkucu MA, Bakır E, Taner Z, Özalp VC, et al. Karbapeneme dirençli enterik bakterilerde isepamisin, kloramfenikol ve minosiklin duyarlılığının araștırılması. Klimik J 2018;31:20-6.

6. National Center for Emerging and Zoonotic Infections Diseases, Division of Healthcare Qual,ty Promotion. CRE toolkit - Guidance for control of carbapenem-resistant Enterobacteriaceae (CRE). Atlanta: CDC, 2012.

7. Correa L, Martino MD, Siqueira I, Pasternak J, Gales AC, Silva CV, et al. A hospital-based matched case-control study to identify clinical outcome and risk factors associated with carbapenem-resistant Klebsiella pneumoniae infection. BMC Infect Dis 2013;13:80.
8. Tuon FF, Graf ME, Merlini A, Rocha JL, Stallbaum S, Arend $L N$, et al. Risk factors for mortality in patients with ventilator-associated pneumonia caused by carbapenem-resistant Enterobacteriaceae. Braz J Infect Dis 2017;21:1-6.

9. Eser F, Yilmaz GR, Guner R, Hasanoglu I, Urkmez Korkmaz $F Y$, Acikgoz ZC, et al. Risk factors for rectal colonization of carbapenem-resistant Enterobacteriaceae in a tertiary care hospital: a case-control study from Turkey. Turkish journal of medical sciences 2019;49:341-6.

10. Girometti N, Lewis RE, Giannella M, Ambretti S, Bartoletti $M$, Tedeschi S, et al. Klebsiella pneumoniae bloodstream infection: epidemiology and impact of inappropriate empirical therapy. Medicine (Baltimore) 2014;93:298-309.

11. Borer A, Saidel-Odes L, Riesenberg K, Eskira S, Peled N, Nativ $R$, et al. Attributable mortality rate for carbapenem-resistant Klebsiella pneumoniae bacteremia. Infect Control Hosp Epidemiol 2009;30:972-6.

12. Schwaber MJ, Klarfeld-Lidji S, Navon-Venezia S, Schwartz $D$, Leavitt A, Carmeli Y. Predictors of carbapenem-resistant Klebsiella pneumoniae acquisition among hospitalized adults and effect of acquisition on mortality. Antimicrob Agents Chemother 2008;52:1028-33.

13. Gomez-Simmonds $A$, Greenman $M$, Sullivan SB, Tanner JP, Sowash MG, Whittier S, et al. Population structure of Klebsiella pneumoniae causing bloodstream infections at a New York City tertiary care hospital: diversification of multidrug-resistant isolates. J Clin Microbiol 2015;53:2060-7.

14. Hussein K, Raz-Pasteur A, Finkelstein R, Neuberger A, Shachor-Meyouhas $Y$, Oren I, et al. Impact of carbapenem resistance on the outcome of patients' hospital-acquired bacteraemia caused by Klebsiella pneumoniae. I Hosp Infect 2013:83:307-13.

15. Aloush V, Navon-Venezia S, Seigman-Igra Y, Cabili S, Carmeli $Y$. Multidrug-resistant Pseudomonas aeruginosa: risk factors and clinical impact. Antimicrob Agents Chemother 2006;50:43-4.

16. Önal U, Sipahi OR, Pullukçu H, Yamazhan T, Arda B, Ulusoy $S$, et al. Retrospective evaluation of the patients with urinary tract infections due to carbapenemase producing Enterobacteriaceae. / Chemother 2019:1-6.

17. Wang Q, Zhang Y, Yao X, Xian H, Liu Y, Li H, et al. Risk factors and clinical outcomes for carbapenem-resistant Enterobacteriaceae nosocomial infections. Eur J Clin Microbiol Infect Dis 2016;35:1679-89.

18. Falagas ME, Rafailidis PI, Kofteridis D, Virtzili S, Chelvatzoglou FC, Papaioannou V, et al. Risk factors of carbapenem-resistant Klebsiella pneumoniae infections: a matched case control study. I Antimicrob Chemother 2007;60:1124-30.

19. Patel G, Huprikar S, Factor SH, Jenkins SG, Calfee DP. Outcomes of carbapenem-resistant Klebsiella pneumoniae infection and the impact of antimicrobial and adjunctive therapies. Infect Control Hosp Epidemiol 2008;29:1099-106.

20. Dizbay M, Guzel Tunccan O, Karasahin O, Aktas F. Emergence of carbapenem-resistant Klebsiella spp. infections in a Turkish university hospital: epidemiology and risk factors. I Infect Dev Ctries 2014;8:44-9. 
21. Souli M, Galani I, Antoniadou A, Papadomichelakis E, Poulakou G, Panagea $T$, et al. An outbreak of infection due to beta-Lactamase Klebsiella pneumoniae carbapenemase 2-producing K. pneumoniae in a Greek University Hospital: molecular characterization, epidemiology, and outcomes. Clin Infect Dis 2010;50:364-73

22. Tumbarello $M$, Viale $P$, Viscoli $C$, Trecarichi EM, Tumietto $F$, Marchese $A$, et al. Predictors of mortality in bloodstream infections caused by Klebsiella pneumoniae carbapenemase-producing K. pneumoniae: importance of combination therapy. Clin Infect Dis 2012;55:943-50.

23. Neuner EA, Yeh JY, Hall GS, Sekeres J, Endimiani A, Bonomo $R A$, et al. Treatment and outcomes in carbapenem-resistant Klebsiella pneumoniae bloodstream infections. Diagn Microbiol Infect Dis 2011;69:357-62.

24. Nguyen $M$, Eschenauer GA, Bryan M, O'Neil K, Furuya EY, Della-Latta $P$, et al. Carbapenem-resistant Klebsiella pneumoniae bacteremia: factors correlated with clinical and microbiologic outcomes. Diagn Microbiol Infect Dis 2010;67:180-4.

25. Ben-David D, Kordevani R, Keller N, Tal I, Marzel A, GalMor $O$, et al. Outcome of carbapenem resistant Klebsiella pneumoniae bloodstream infections. Clin Microbiol Infect 2012;18:54-60.

26. Daikos GL, Petrikkos P, Psichogiou M, Kosmidis C, Vryonis $E$, Skoutelis $A$, et al. Prospective observational study of the impact of VIM-1 metallo-beta-lactamase on the outcome of patients with Klebsiella pneumoniae bloodstream infections. Antimicrob Agents Chemother 2009;53:1868-73.
27. Candevir Ulu A, Kurtaran B, Inal AS, Komur S, Kibar F, Yapici Cicekdemir $H$, et al. Risk factors of carbapenem-resistant Klebsiella pneumoniae infection: a serious threat in ICUs. Med Sci Monit 2015;21:219-24.

28. Marinosci F, Zizzo A, Coppola A, Rodano L, Laudisio A, Antonelli Incalzi $R$. Carbapenem resistance and mortality in institutionalized elderly with urinary infection. J Am Med Dir Assoc 2013;14:513-7.

29. Qureshi ZA, Paterson DL, Potoski BA, Kilayko MC, Sandovsky G, Sordillo E, et al. Treatment outcome of bacteremia due to KPC-producing Klebsiella pneumoniae: superiority of combination antimicrobial regimens. Antimicrob Agents Chemother 2012;56:2108-13.

30. Liang $Q$, Huang $M, X u Z$. Early use of polymyxin B reduces the mortality of carbapenem-resistant Klebsiella pneumoniae bloodstream infection. Braz J Infect Dis 2019;23:60-5.

31. Evren E, Azap OK, Colakoglu S, Arslan H. In vitro activity of fosfomycin in combination with imipenem, meropenem, colistin and tigecycline against OXA 48-positive Klebsiella pneumoniae strains. Diagn Microbiol Infect Dis 2013;76:335-8

\section{Address for Correspondence/Yazıșma Adresi}

\section{Uzm. Dr. Gönül CíCEK SENTÜRK}

Dıșkapı Yıldırım Beyazıt Eğitim ve

Araștırma Hastanesi, İnfeksiyon Hastalıkları ve Klinik Mikrobiyoloji Kliniŏi,

Ankara-Türkiye

E-mail: drgonulcicek@hotmail.com 